\title{
Assessment of Genetic Variability among Some Rabbit Breeds Using Random Amplified Polymorphic DNA Technique (RAPD)
}

\author{
EL-Shawaf, I.I.S ${ }^{1}$, Khalil M.H², Refaat M.H' ${ }^{1}$, El-Zarei M.F ${ }^{3}$ and Omnia A.Badr ${ }^{1}$ \\ ${ }^{1}$ Department of Genetics and Genetic engineering, Faculty of Agriculture at Moshtohor, Benha University, \\ Egypt. \\ ${ }^{2}$ Department of Animal Production, Faculty of Agriculture at Moshtohor, Benha University,Egypt. \\ 3Department of Animal Production, Faculty of Agriculture, Suez Canal University, Ismailia, Egypt
}

\begin{abstract}
Random Amplified Polymorphic DNA (RAPD) marker was employed to assess the genetic variation and phylogenetic relationship among four rabbit breeds viz. New Zealand White, Gabali, Baladi Red and Baladi Black reared in Egypt. Initially, a total of 14 random primers of arbitrary sequence were used but 10 of them generated reproducible, scoreable and polymorphic bands. Out of 131 bands scored using these primers, $74(56.48 \%)$ were recognized as Polymorphic and 57 (43.52\%) as monomorphic bands. The highest percentage of polymorphic bands was recognized for primers OPB-02 (94\%) and OPB-07 (92\%). While, the lowest percentage of polymorphic bands was recognized for primers OPA-02(16\%) and OPF-12 (28\%). The band sharing frequencies (BSF) was found higher between Baladi Red -Baladi Black $(0.80 \pm 0.038$ ), followed by Gabali - Baladi Black $(0.71 \pm 0.079$ ), New Zealand White- Baladi Black (0.70 \pm 0.096 ), New Zealand Whit- Baladi Red (0.69 \pm 0.088 )and the least BSF was found between New Zealand Whit- Gabali $(0.64 \pm 0.081)$. Overall, there was no significant difference $(\mathrm{P}>0.05)$ in BSF values between breeds. The highest genetic distance was found between Baladi Red -Baladi Black (0.87) followed by Gabali, Baladi Red (0.86), Gabali, Baladi Black(0.82), New Zealand White, Gabali (0.80), New Zealand White,Baladi Red $(0.75)$ and the lowest genetic distance was found between New Zealand White,Baladi Black(0.73). One primer (OPA-20) in Gabali, two primers(OPA-02,OPB-14) in Baladi Red, three primers (OPA-02,OPB-14, OPA-20) in New Zealand White and Baladi Black were found to be specific for these breeds. The study suggests that RAPD can be successfully utilized for detecting genetic variation among the studied rabbit breeds.
\end{abstract}

Key words: Rabbit, breed, RAPD markers, genetic diversity, phylogenetic, BSF (Band sharing frequency)

\section{Introduction}

Egypt is a country that produces rabbit meat in family farms; tries to develop industrialized rabbit production and has a very important research structure related to rabbit science and technology (El-Raffa et al.,2005). The genetic researches in Egypt concerning rabbits had concentrated mainly in the studies describing the local and exotic breeds, Gabali, Baladi Black and Baladi Red were described as local breeds adapted to hot climate and somewhat resistant to diseases CIHEAM ,(2002) In the last decade, popular meat breed (New Zealand White) of rabbit was introduced in Egypt, being used in large scale of commercial production throughout Egypt. New Zealand White exhibits outstanding maternal abilities as related to maternal behavior, fecundity, lactation, and preweaning growth and survival (Khalil, 1993). Recently, the rabbit has attracted more attention from the biotechnology community. The rabbit genome is estimated to be 3 billion base pairs long, almost equal to the size of the human genome. Also, rabbits have similar lipid metabolism to humans, making them good models of atherosclerosis (Dove, 2000).

Characterization at the molecular level is undertaken mainly to explore genetic diversity within and between animal populations, and to determine genetic relationships among these populations. The estimation of genetic variability of a species is an important criterion for its conservation and for further genetic improvement (Rahimi et al., 2005). Molecular markers derived from polymerase chain reaction (PCR) amplification of genomic DNA are an important part of the toolkit of evolutionary geneticists (Holsinger et al., 2002). By detecting genetic variation, genetic markers may provide useful information at different levels; population structure, levels of gene flow, phylogenetic relationships, patterns of historical biogeography and the analysis of parentage and relatedness (Feral, 2002). PCR based on multilocus DNA fingerprints represent one of the most informative and cost-effective measures of genetic diversity (Bagley et al., 2001). Randomly Amplified Polymorphic DNA (RAPD) technique, described firstly by Williams et al., (1990), is a simple, fast and comparatively low cost assay that uses short oligonucleotide primers of arbitrary sequences to amplify anonymous fragments of genomic DNA (Stepniak et al., 2002), and no prior knowledge of the genome under investigation is necessary to perform the assay (Bowditch et al., 1993). Due to those features, the RAPD analysis has 
found many uses in different fields of study in both plants and animals. Polymorphism of RAPD fragments is detected as a band's presence or absence and may result from deletion, insertion or differences in the nucleotide sequences in or between the priming regions (Clark and Lanigan, 1993). RAPD markers are the randomly amplified target regions of less functional part of the genome that do not strongly respond to selection on the phenotype level. Such amplified regions may accumulate more mutations thereby offering a wider potential in assessing the interbreed/population genetic differentiation. The objective of this study was to assess the genetic diversity and phylogenetic relationship among four rabbit breeds viz. New Zealand White, Gabali, Baladi Red and Baladi Black using Random Amplified Polymorphic DNA (RAPD) Markers.

\section{Materials and Methods}

This research was performed in the Department of Genetics and Genetic Engineering (Biotechnology Services Unit), Faculty of Agriculture, Benha University.

\section{Experimental Animal Used:}

A total of sixty rabbits viz. 15 rabbits each in New Zealand White (NEW), Gabali (G), Baladi Red (BR) and Baladi Black (BB) were taken for this study. The animals selected from four accredited farms viz. The rabbitry of the Department of Animal Production, Faculty of Agriculture, Benha University, Egypt; Inshas, Gimmeza and Shakha Experimental Rabbitries, which belong to Animal Production Research Institute (APRI) Agricultural Research Center (ARC), Ministry of Agriculture, Egypt. The animals were taken randomly from pedigreed animals with the least relationship to decrease the genetic similarity and to have more chance to have more polymorphism in markers alleles. We identified the animals depending on their pedigrees to be sure that these animals not full-sib or half-sibs. In addition, we check these relationships by analyzing the polymorphism after genotyping to insure that there is no error in their original farm pedigree.

\section{Blood samples and DNA extraction:}

DNA of each breed were extracted from whole fresh blood samples, approximately $5 \mathrm{ml}$ blood was collected from the central artery vein of the ear of animal into tubes containing Ethylene diamine tetra acetic acid (EDTA) as anticoagulant. The blood samples were kept in Ice tank till reaching the laboratory and were then preserved in a freezer at $20^{\circ} \mathrm{C}$. Until extraction of DNA. Genomic DNA was extracted from leukocytes using the Promega Wizard Genomic DNA Purification Kit (Cat No. A 1120) using the manufacture protocol.

\section{RAPD-PCR conditions and Electrophoresis:}

A total of fourteen random primers (Operon Technologies Inc, USA) of arbitrary sequence with $60-70 \%$ GC content were screened on pooled rabbit DNA but ten of them generated reproducible, scoreable and polymorphic bands Table (1). The amplification reaction was carried out in $25 \mu \mathrm{l}$ final volume containing $2 \mu \mathrm{l}$ template $\mathrm{DNA}, 3 \mu \mathrm{l}$ primer (10 pmol/ $\mu \mathrm{l}), 5 \mu \mathrm{l}$ (5X PCR buffer ), $0.2 \mu \mathrm{l}$ Taq polymerase $(5 \mathrm{U} / \mu \mathrm{l}), \quad 2.5 \mu \mathrm{l} \quad \mathrm{dNTP}$ 's $\operatorname{mix}(2 \mathrm{mM})$ ;(dATP, dCTP, dTTP and dGTP), $2 \mu \mathrm{l} \mathrm{MgCl} 2$ $(25 \mathrm{mM})$ and $10.3 \mu \mathrm{ldd}-\mathrm{H} 2 \mathrm{O}$. PCR amplification was performed in a GeneAmp® PCR System 9700 (Applied Biosystems, Foster City, California, USA), with the following amplification conditions: initial denaturation at $94^{\circ} \mathrm{C}$ for $4 \mathrm{~min}$, followed by denaturation at $94^{\circ} \mathrm{C}$ for $40 \mathrm{sec}$, annealing at $36^{\circ} \mathrm{C}$ for $1 \mathrm{~min}$, extension at $72^{\circ} \mathrm{C}$ for $1 \mathrm{~min}$ for 35 cycles and final extension at $72^{\circ} \mathrm{C}$ for $10 \mathrm{~min}$. The PCR products were run on $1.5 \%$ agarose gel. Gel Documentation System (Gel-Doc 2000 with Diversity Database software Ver. 2.1, Bio-Rad Laboratories, Hercules, California, USA) was used for gel documentation and gel analysis.

Table 1. List of random amplified polymorphic DNA primers (RAPD) and their nucleotide sequence.

\begin{tabular}{llllll}
\hline Primer code & $\begin{array}{c}\text { Nucleotide Sequence } \\
\left(5^{\prime} \rightarrow 3^{\prime}\right)\end{array}$ & G+C $(\%)$ & Primer code & $\begin{array}{c}\text { Nucleotide Sequence } \\
\left(5^{\prime} \rightarrow 3^{\prime}\right)\end{array}$ & $\begin{array}{l}\text { G+C } \\
(\%)\end{array}$ \\
\hline OPA-09 & 5'-GGGTAACGCC -3' & $70 \%$ & OPA-20 & 5'-GTTGCGATCC-3' & $60 \%$ \\
OPB-05 & 5'-TGCGCCCTTC -3' & $70 \%$ & OPF-09 & 5'-CCAAGCTTCC-3' & $60 \%$ \\
OPB-07 & 5'-GGTGACGCAG -3' & $70 \%$ & OPF-12 & 5'-ACGGTACCAG-3' & $60 \%$ \\
OPB-14 & 5'-TCCGCTCTGG -3' & $70 \%$ & OP-B2 & 5'-TGATCCCTGG-3' & $60 \%$ \\
OPA-19 & 5'-CAAACGTCGG-3' & $60 \%$ & OP-A2 & 5'-TGCCGAGCTG-3' & $70 \%$ \\
\hline
\end{tabular}

\section{Analysis of RAPD data:}

Only distinct and clear bands of RAPD products on agarose gel were scored. The presence and absence of band was recorded as "1" and " 0 ", respectively. The binary coded characters $(1,0)$ were used for the genetic analysis.
Band Sharing Frequency (BSF) was used to estimate the genetic similarity for each primer (Lynch, 1990) and a simple expression of similarity measured in terms of sharing bands between breeds.

\section{Band Sharing Frequency (BSF)}


Band Sharing Frequency (BSF) was calculated as an expression of animals from either the same or different breeds using the following formula (Jeffery and Morton, 1987).

$\mathrm{BSF}=2 \mathrm{Nab} /(\mathrm{Na}+\mathrm{Nab})$

Whereas, Nab is the number of bands common to a and $\mathrm{b}$ individual, $\mathrm{Na}$ is the number of bands present in the animal $\mathrm{a}$, while $\mathrm{Nb}$ is the number of bands present in the animal $b$. The BSF values between breeds will be statistically analyzed by analysis of variance procedure using SAS 2004 program. Significant differences between means will be detected using Duncan's multiple range test (Kramer, 1957).

\section{Genetic Distance (D)}

Genetic distances are designed to express the genetic differences between two populations as a single number. If there are no differences, the distances could be set to zero, whereas, if the population have no allele in common at any locus the distance may be set equal to its maximum value. The genetic distances (D) were calculated by POPGENE software (Yeh et al.,1999) using Nei (1978) standard genetic distance equation.

\section{Phylogenetic relationship}

The phylogenetic relationship among rabbit breeds was analyzed by generating the phylogenetic tree by $\mathbf{N e i}(\mathbf{1 9 7 2})$ genetic distances using UPGMA analysis through POPGENE software (Yeh et al.,1999).

\section{Results and Discussion}

In the present study, RAPD technique was used to assess the genetic variability and phylogenetic relationship among four rabbit breeds. Fourteen random primers were tested to amplify pooled genomic DNA from these breeds. Ten of them were chosen for further analysis, on the basis of the presence of reproducible and distinct RAPD profiles in one or more rabbit breeds (Figure 1). These primers amplified on average 2 to 14 bands of sizes varying from 200bp to $2000 \mathrm{bp}$. This observed range of products presumably due to limitations in the resolving power of the agarose gels at lower molecular weights as well as inefficiency of the extension reaction under the described PCR conditions at higher molecular weights (Bowditch et al., 1993). A total of 131 diagnostic bands were scored within RAPD profiles amplified by these 10 primers. The number of detected bands (TDB) per primers, number of polymorphic bands (NPB) and percent of polymorphic bands (PB) are presented in Table (2). Among 131 scorable bands $74(56.48 \%$ )were recognized as polymorphic and $57(43.52 \%)$ as monomorphic bands Table (2). The average number of polymorphic bands per primer varied from 2 to 17 . The highest percentage of polymorphic bands was recognized for primers OPB-02 (94\%)and OPB-07(92\%) while the lowest percentage of polymorphic bands was recognized for primers OPA-02(16\%) and OPF-12 (28\%), Table (2).

Table 2. Summary of the results of RAPD analysis with 10 random primers: total number of detected bands

(TDB), number of polymorphic bands (NPB) and percentage of polymorphic bands (PB \%).

\begin{tabular}{llllllll}
\hline Primers & TDB & NPB & PB & Primers & TDB & NPB & PB \\
\hline OPA-09 & 13 & 9 & $69 \%$ & OPA-20 & 8 & 4 & $50 \%$ \\
OPB-05 & 9 & 5 & $55 \%$ & OPF-09 & 15 & 6 & $40 \%$ \\
OPB-07 & 13 & 12 & $92 \%$ & OPF-12 & 14 & 4 & $28 \%$ \\
OPB-14 & 14 & 9 & $64 \%$ & OPB-02 & 18 & 17 & $94 \%$ \\
OPA-19 & 15 & 6 & $40 \%$ & OPA-02 & 12 & 2 & $16 \%$ \\
& \multicolumn{2}{c}{ TOTAL } & & & 131 & 74 & $56.48 \%$ \\
\hline
\end{tabular}

The number of bands amplified per primer was variable among the four rabbit breeds Table (3). The maximum numbers of bands were found in New Zealand White (14) followed by Gabali, Baladi Black and Baladi Red (13) using primer OPF-9. Primer OPF-9 gave the maximum numbers of bands (53) while the minimum numbers of bands were obtained using primer OPB-5 (18). Khalil, et al., (2008) studied association between RAPD markers and some reproductive traits in rabbits. They found five polymorphic fragments at molecular weight of 1500, 1100, 1200, 700 and $900 \mathrm{bp}$, respectively for five RAPD markers (OPA-12, OPA-19, OPA-20, OPF-09, and OPF-12) linked to these reproductive traits. In a similar study conducted by El Sayed (2010), he used eight RAPD primers (OPA-10, OPB-05, OPC-01, OPC02, OPC-08, OPE-11, OPE-19 and OPX-02) to assess the genetic diversity among six rabbit breeds viz; New Zealand White, Black Rex, Hyplus strain, Spanish line V, Moshtohor or Line M, and Sinai. He found that, all primers yielded informative and identifiable bands revealing genetic differences between breeds. 


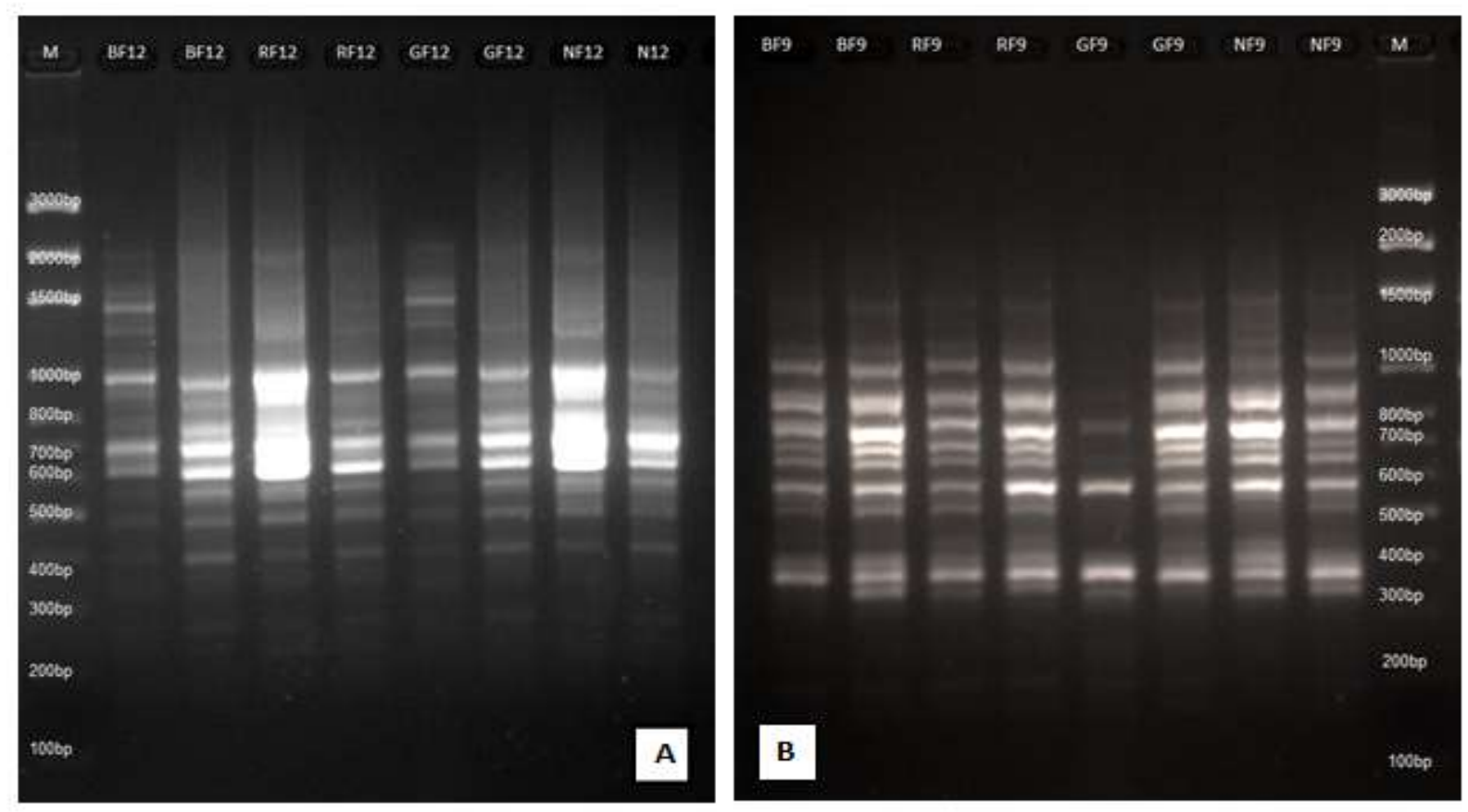

Figure 1. RAPD profile in different rabbit breeds; NZW: New Zealand White, G: Gabali, B: Baladi Black and R: Baladi Red using primers; A: OPF-12 and B: OPF-09 Molecular marker (100 bp plus ladder).
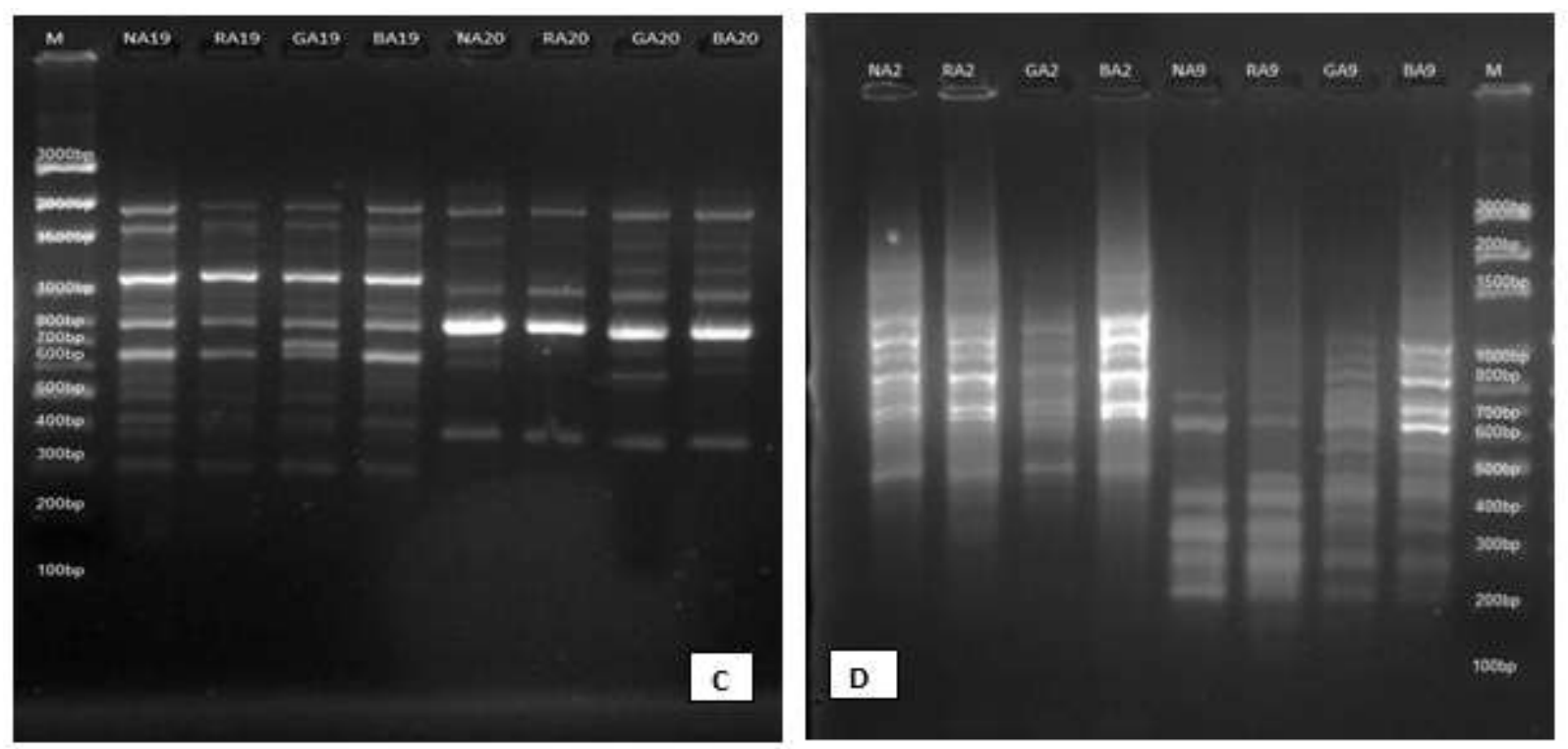

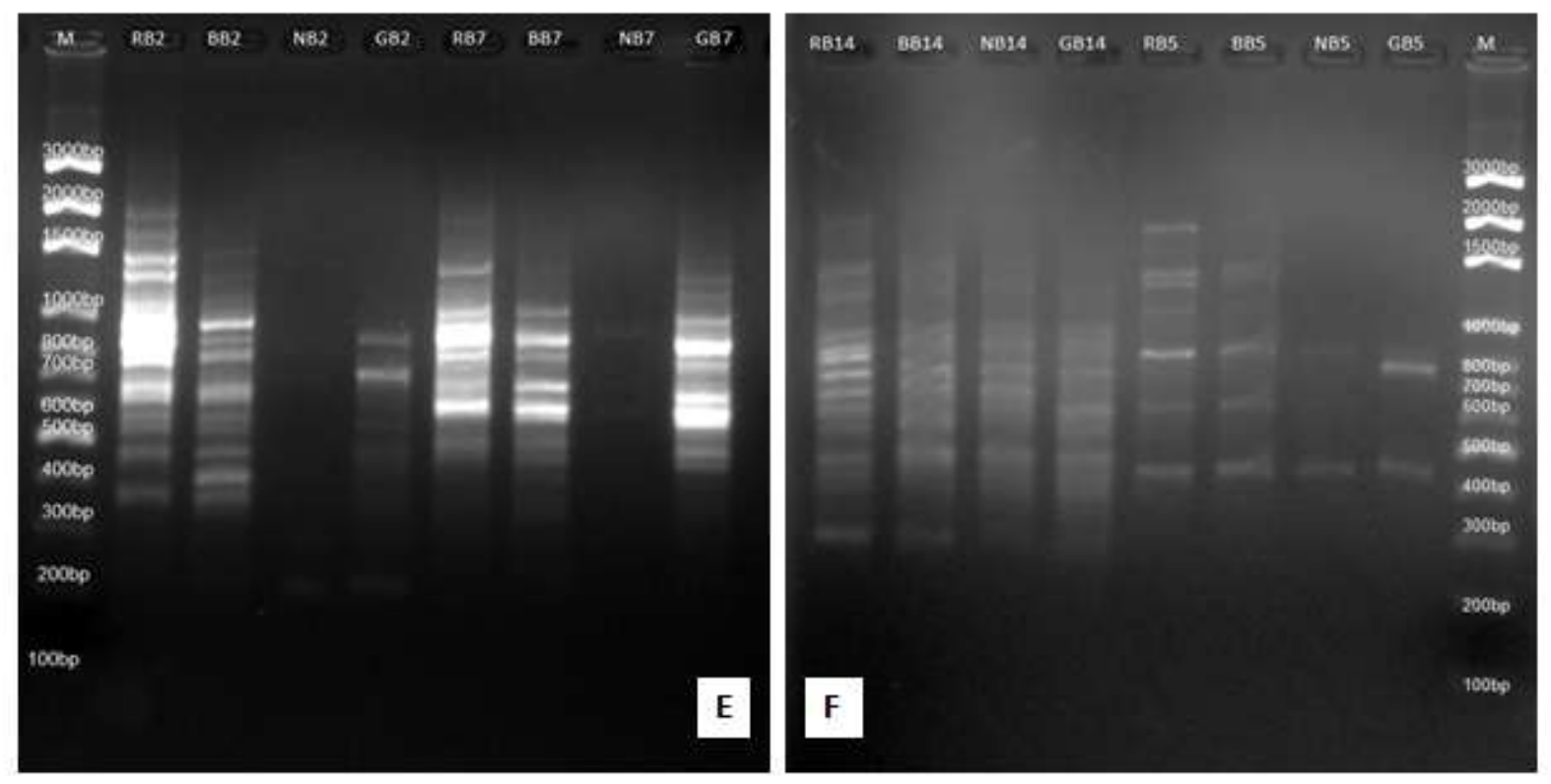

Figure 2. RAPD profile in different rabbit breeds; NZW: New Zealand White, G: Gabali, B: Baladi Black and R: Baladi Red using primers; C: OPA-19 and OPA-20; D: OPA-02 and OPA-09; E: OPB-02 and OPB-07; F: OPB-14 and OPB-5. Molecular marker (100 bp plus ladder).

Table (3): Number of bands per primer in different rabbit breeds.

\begin{tabular}{|c|c|c|c|c|c|}
\hline RAPD Primer & NEW & $\mathrm{G}$ & $\mathrm{BB}$ & BR & TOTAL \\
\hline OPA-09 & 6 & 12 & 11 & 7 & 36 \\
\hline OPB-05 & 2 & 3 & 6 & 7 & 18 \\
\hline OPB-07 & 2 & 9 & 9 & 7 & 27 \\
\hline OPB-14 & 8 & 9 & 9 & 14 & 40 \\
\hline OPA-19 & 12 & 11 & 12 & 10 & 45 \\
\hline OPA-20 & 6 & 7 & 7 & 4 & 24 \\
\hline OPF-09 & 14 & 13 & 13 & 13 & 53 \\
\hline OPF-12 & 11 & 11 & 12 & 12 & 46 \\
\hline OPB-02 & 3 & 6 & 12 & 14 & 35 \\
\hline OPA-02 & 10 & 9 & 11 & 10 & 36 \\
\hline TOTAL & 74 & 90 & 102 & 98 & 324 \\
\hline
\end{tabular}

Similar type of the study was conducted by Mamuris et al., (2002) they used RAPD primers (OPA-02, OPA-09, OPA-10, OPA-20 and OPF-01) for assessment of genetic variability among brown hare (L.europaeus) population from different geographical regions. In their study, all primers produced polymorphic bands in the range of 5 to 11 . Rangoju et al., (2007) assessed genetic variability and phylogenetic relationship among three rabbit breeds using six random primers (OPA-01, OPA08, OPA-10,OPA-18, OPB-03 and OPB-05). They found that, the maximum number of bands was (13.2 \pm 0.4$)$, while minimum number of bands were $(6.4 \pm 0.2)$ in all the breeds. In a similar study conducted by El-Bayomi Kh. M et al.,(2013) they used RAPD primers (OPA-01, OPA-06, OPA-10, OPB-05, OPB-13, OPB-14,OPC-01,OPC-02,OPC08,OPE-19,OPE-11,OPF-9,OPF-12and OPX-02) for assessment of genetic variability among three rabbit breeds. They found that, The highest percentage of polymorphic bands was recognized for primers OPA-10 and OPA-06 (56\%) while the lowest percentage of polymorphic bands was recognized for primers OPE-19 (7\%) and OPF-12 $(14 \%)$.

\section{RAPD markers for breed differentiation:}

The RAPD profiles of New Zealand White, Gabali, Baladi Black and Baladi Red breeds generated by 10 random primers were studied for identifying breed specific markers i.e. the marker unique to a particular breed only Table (4). One primer (OPA-19) was identified in New Zealand White. Three primers (OPB-02, OPA-02 and OPA19) were identified in Baladi Black .Four primers (OPA-19, OPA-20, OPB-05 and OPB-07) were identified in Gabali. Five primers (OPB-05, OPB-02, OPA-19, OPF-12 and OPB-14) were identified in Baladi Red, Table (4). These breed specific primers can be used in identification of the breeds. However, these results need to be validated by using large sample size. 
Table 4. Specific RAPD markers in the four rabbit breeds.

\begin{tabular}{|c|c|c|c|c|}
\hline No. & Molecular marker & Band number & Molecular weight & Breed \\
\hline 1 & OPF-12 & 2 & $1600 \mathrm{bp}$ & $\mathrm{RB}$ \\
\hline 2 & OPA-02 & 1 & $2050 \mathrm{bp}$ & $\mathrm{BB}$ \\
\hline \multirow[t]{4}{*}{3} & OPA-19 & 3 & $1500 \mathrm{bp}$ & BB \\
\hline & & 6 & $920 \mathrm{bp}$ & $\mathrm{RB}$ \\
\hline & & 9 & $720 \mathrm{bp}$ & $\mathrm{G}$ \\
\hline & & 14 & $360 \mathrm{bp}$ & NEW \\
\hline 4 & OPA-20 & 7 & $550 \mathrm{bp}$ & $\mathrm{G}$ \\
\hline \multirow[t]{2}{*}{5} & OPB-14 & 1 & $1880 \mathrm{bp}$ & $\mathrm{RB}$ \\
\hline & & 12 & 440 bp & $\mathrm{RB}$ \\
\hline \multirow[t]{3}{*}{6} & OPB-05 & 1 & $1880 \mathrm{bp}$ & $\mathrm{RB}$ \\
\hline & & 6 & 860 bp & $\mathrm{G}$ \\
\hline & & 7 & 790 bp & G \\
\hline \multirow[t]{3}{*}{7} & OPB-07 & 2 & $1250 \mathrm{bp}$ & $\mathrm{G}$ \\
\hline & & 4 & $970 \mathrm{bp}$ & $\mathrm{G}$ \\
\hline & & 8 & $620 \mathrm{bp}$ & $\mathrm{G}$ \\
\hline \multirow[t]{6}{*}{8} & OPB-02 & 1 & $2000 \mathrm{bp}$ & $\mathrm{RB}$ \\
\hline & & 2 & $1750 \mathrm{bp}$ & $\mathrm{RB}$ \\
\hline & & 3 & $1500 \mathrm{bp}$ & BB \\
\hline & & 4 & $1400 \mathrm{bp}$ & $\mathrm{RB}$ \\
\hline & & 7 & $1000 \mathrm{bp}$ & RB \\
\hline & & 16 & $400 \mathrm{bp}$ & BB \\
\hline
\end{tabular}

Band Sharing Frequency (BSF) is an indicator of relatedness between breeds ( $\mathrm{Nei} \& \mathrm{Li}, \mathrm{1979})$. Interbreed BSF being the highest between Baladi

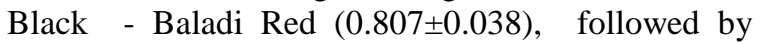
Gabali- Baladi Black $(0.711 \pm 0.079)$ and the lowest between New Zealand White- Gabali
(0.649 \pm 0.081$) \quad$ Table (5). Similarity between fingerprint patterns expressed by band sharing values provides a reliable method for evaluating genetic distance among population (Kuhnlein et al., 1989 and Dunnington et al., 1991).

Table 5. Band sharing frequency between rabbit breeds.

\begin{tabular}{ccccccc}
\hline RAPD & & & & & & \\
Primer & NEW-G & NEW-BB & NEW-BR & G-BB & G-BR & BR-BB \\
\hline OPA-09 & 0.55 & 0.47 & 0.92 & 0.95 & 0.63 & 0.55 \\
OPB-05 & 0.4 & 0.5 & 0.44 & 0.22 & 0.2 & 0.92 \\
OPB-07 & 0.18 & 0.36 & 0.44 & 0.55 & 0.37 & 0.75 \\
OPB-14 & 0.58 & 0.94 & 0.72 & 0.55 & 0.78 & 0.78 \\
OPA-19 & 0.86 & 0.91 & 0.81 & 0.86 & 0.85 & 0.81 \\
OPA-20 & 0.76 & 0.92 & 0.8 & 0.85 & 0.72 & 0.72 \\
OPF-09 & 0.88 & 0.88 & 0.88 & 0.84 & 0.84 & 0.92 \\
OPF-12 & 0.9 & 0.95 & 0.86 & 0.95 & 0.86 & 0.91 \\
OPB-02 & 0.44 & 0.13 & 0.11 & 0.44 & 0.4 & 0.76 \\
OPA-02 & 0.94 & 0.95 & 1 & 0.9 & 0.94 & 0.95 \\
Overall & & & & & & $0.659 \pm 0.075$ \\
S.E & $0.649 \pm 0.0815$ & $0.701 \pm 0.096$ & $0.698 \pm 0.088$ & $0.711 \pm 0.079$ & $0.807 \pm 0.038$ \\
\hline
\end{tabular}

Rangoju et al., (2007) studied genetic variation among three rabbit breeds viz. White Giant (WG), Soviet Chinchilla (SC) and Grey Giant (GG) using 40 RAPD primers. Six primers were found polymorphic and the overall BSF value between breeds was found higher in SC-GG followed by WG-SC and WG-GG. The Nei's genetic distance (D) of the present study was found highest between
WG-GG followed by WG-SC and SC-GG. Genetic distances among the studied four rabbit breeds were shown in Table (6). The genetic distances ranged from 0.87 between Baladi Black - Baladi Red (more related) to 0.73 between New Zealand White - Baladi Black (distantly related).High value of genetic distance was found between New Zealand White - Gabali (0.80). 
Table 6. Genetic distances between rabbit breeds using RAPD data

\begin{tabular}{lllll}
\hline breed & NEW & G & BR & BB \\
\hline NEW & 1 & 0.808511 & 0.753927 & 0.738462 \\
G & 0.808511 & 1 & 0.860104 & 0.822335 \\
BR & 0.753927 & 0.860104 & 1 & 0.87 \\
BB & 0.738462 & 0.822335 & 0.87 & 1 \\
\hline
\end{tabular}

El Sayed, (2010), found that the highest value of the genetic distances (37.0) was between New Zealand White/Black Rex and New Zealand White/ Spanish Line V while the lowest value was 10.0 between Spanish Line V/ Line M (Moshtohor). The phylogenetic relationships among the studied four rabbit breeds based on genetic distance were given in Figure (2). There were two separate clusters formed from the four rabbit breeds. The local breeds clustered together in one cluster however, New Zealand White breed clustered alone. These variations might be due to the different geographical climatic conditions and/or different races, which cause variability in the gene pool.

\section{Dendrogram using dverage Linkage (Between Groups)}

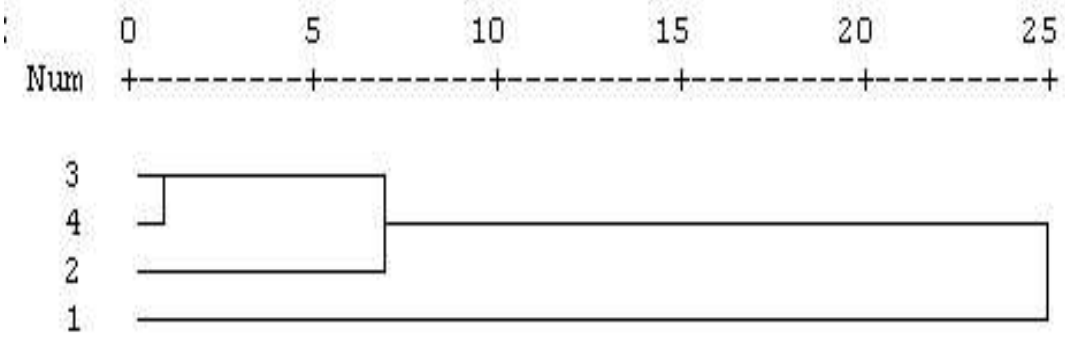

Figure 3. Dendrogram of studied rabbit breeds based on genetic distances: (1) NEW Zealand White. (2) Gabali .

(3) Baladi Black. (4) Baladi Red

In this concept, Rangoju et al., (2007) illustrated the phylogenetic relationship among some rabbit breeds and their dendrogram revealed that Soviet Chinchilla and Grey Giant are closer, while White Giant and Grey Giant are distant to each other. Moreover, El Sayed (2010), showed that Spanish Line V and Line M (Moshtohor) were close to each other while New Zealand White and Hyplus were more distant breeds. and El-Bayomi Kh. M et al.,(2013) showed that New Zealand White and Californian breeds were close to each other while Flander breed was distant to them.

RAPD analysis has been used to discriminate animal species other than rabbits and to determine the genetic diversity and phylogenetic relationship between animals such as cattle breeds (Rincón et al.,2000; Ramadan, 2004; Devrim and Kaya, 2006 \& Joshi et al., 2007). Buffalo (Sodhi et al., 2006; \& Abdel-Rahman and Hafez, 2007). Horse breeds (Alves do Egito et al., 2007 \& Saleh, 2011). Sheep and goat (Ali, 2003; Abd Rabou, 2007; Elmaci et al., 2007; Mahfouz, et al., 2008 \& Kunene et al.,2009). Chicken (Zhang et al., 2002; \& Ahlawat et al., 2004 \& El Araby, 2006 ) .Geese (Maciuszonek et al., 2005). Quail (Sharma et al., 2000). Duck breeds (El-Gendy et al., 2005 \& Gholizadeh et al., 2007). Turkey breeds (Smith et al., 2005) and fish species
(Callejas and Ochando, 2002; Hassanien, 2004 \& Abel Wahab, 2009).

\section{Conclusion}

The present study suggests that RAPD can be used as a tool to understand the genetic variability and phylogenetic relationship among rabbit breeds. The wide genetic diversity between New Zealand White and local breeds allows scientists' for further research in rabbit breeding programs to obtain hybrid vigor and improve rabbit production. The study also provided unique molecular genetic markers for the studied rabbit breeds which may be useful in differentiating between these breeds at the molecular level.

\section{References}

Abd Rabou, S.M.N. (2007): Molecular genetic studies on some Egyptian farm animals. MVSc thesis, Faculty of Veterinary Medicine, Alexandria University, Egypt.

Abdel Wahab, A. (2009): Some genetic studies on Tilapia fish. Ph. D. thesis, Faculty of Veterinary Medicine, Suez Canal University, Egypt.

Abdel-Rahman, S.M. and Hafez, E.E. (2007): Genetic Similarity Among the Three Egyptian Water Buffalo Flocks Using 
RAPD-PCR and PCR-RFLP Techniques. Research J. Agri. and Bio. Sci. 3 (5): 351355.

Ahlawat, S.P.; Sunder, J.; Kundu, A.; Chatterjee, R.N.; Rai, R.B.; Kumar, B.; Senani, S.; SahaS.K. and Yadav, S.P. (2004): Use of RAPD-PCR for Genetic Analysis of Nicobari Fowl of Andamans. British Poultry Science, 45(2): 194-200.

Ali, B. (2003): Genetics similarity among four breeds of sheep in Egypt detected by random amplified polymorphic DNA markers. Afric. J. Bio. 2: 194-197.

Alves do Egito, A.; Fuck, B.H.; McManus, C.; Paiva, S.R.; Albuquerque, M.M.; Santos, S.A.; Pinto de Abreu, U.G.; Augusto da Silva, J.; Sereno, F.T.P. and Mariante, A.S. (2007): Genetic variability of Pantaneiro horse using RAPD-PCR markers. Revista Brasileira de Zootecnia, 36(4): 799806.

Bagley, M.J.; Anderson, S.L.; and May, B. (2001):Choice of methodology for assessing genetic impacts of environmental stressors: polymorphism and reproducibility of RAPD and AFLP fingerprints. Ecotoxicology 10: 239244.

Bowditch B.M., Albright D.G., Williams J.G. and Braun M.J. (1993): Use of randomly amplified polymorphic DNA markers in comparative genome studies. Methos Enzymol. 224: 294-309.

Callejas, C. and Ochando, M.D. (2002):Phylogenetic relationships among Spanish barbus species (Pisces, Cyprinidae) shown by RAPD markers. Heredity, 89: 3643.

CIHEAM, (2002): Rabbit genetic resources in Mediterranean countries. Zaragoza:p. 41- 64 (Options Méditerranéennes Série B. Etudes et Recherches; n. 38)

Clark A.G. and Lanigan M.S. (1993): Prospects for estimating nucleotide divergence with RAPDs. Mol Biol Evol. 10: 1096-1111

Devrim, A.K. and Kaya, N. (2006): An investigation on DNA polymorphism of the cattle breeds in the province of Kars by RAPD-PCR technique. Revue de Médecine Vétérinaire, 157(2): 88-91.

Dove, A. (2000). Milking the genome for profit. Nat. Biotechnol., 18 (10): 1045-1048.

Dunnington, E.A., Gal, O. and Siegel P.B. (1991): Deoxyribonucleic acid fingerprint comparisons between selected populations of chickens. Poult. Sci., 70: 463-470.

EL Araby, I - (2006): Assessment of genetic diversity and phylogenetic relationships using protein and DNA markers among some chicken breeds in Egypt. Ph. D. thesis,
Faculty of Veterinary Medicine, Zagazig University, Egypt.

El-Bayomi Kh. M, Awad A and Saleh A. A.(2013): Genetic Diversity and Phylogenetic Relationship among Some Rabbit Breeds Using Random Amplified Polymorphic DNA Markers. Life Science Journal, 2013; 10 (1)

El-Gendy, E.A.; Helal, M.A.; Goher, N.H. and Mostageer, A. (2005): Molecular characterization of genetic biodiversity in ducks, using RAPD-PCR analysis. Arab Journal of Biotechnology, 8(2): 253-264.

Elmaci, C.; Oner, Y; Ozis, S. and Tuncel, E. (2007): RAPD analysis of DNA polymorphism in Turkish sheep breeds. Biochemical Genetics, 45: 6

El-Raffa A.M.; Youssef Y.K.; Iraqi M. M.; Khalil M. H.; García M.L. and Baselga M.(2005): Developing rabbit lines for meat production in Egypt and Saudi Arabia: overview, synthesizing plan, descriptive performance and future prospects. The $4^{\text {th }}$ Inter. Con. on Rabbit Prod. in Hot Clim., Sharm El-Sheikh, Egypt, 47 $-53$.

El Sayed, A.H. (2010): Assessment of Genetic Variability among Some Rabbit Breeds by Random Amplified Polymorphic DNA (RAPD) -PCR. Master thesis, Faculty of Veterinary Medicine, Suez Canal University, Egypt.

Feral, J.P. (2002): How useful is the genetic markers in attempts to understand and manage marine biodiversity. J. Exp. Mar. Biol. Ecol., 268: 121-145.

Gholizadeh, M.; Mianji, Gh.R.; Ghobadi, A.; Zadeh, H.S. and Montazami, Sh. (2007): Measurement of within and between genetic variability in duck breeds by RAPD markers. Pakistan Journal of Biological Sciences, 10 (6): 982-985.

Hassanien, H.A. (2004): The genetic diversity of Nile Tilapia Oreochromis niloticus based on morphometric and molecular markers. Ph.D. Sc. Thesis, Department of Animal Production, Faculty of Agriculture, Cairo University.

Holsinger, K.E.; Lewis, P.O. and Dey, D.K. (2002) : A Bayesian approach to inferring population structure from dominant markers. Mol. Ecol., 11: 1157-1164.

Jeffreys A.J., Morton D.B. 1987. DNA fingerprinting of $\operatorname{dog} s$ and cats.Anim. Genet., 18, 1-15

Joshi, J.; Patel, R.K.; Singh, K.M.; Soni, K.J.; Chauhan, J.B.; Rank, D.N.; Joshi, C.G. and Sambasiva Rao, K.R.S. (2007): Genome identity and diversity study in Gir and Kankrej (Bos indicus) cattle breeds using RAPD fingerprints.Biotechnology, 6 (3): 322327. 
Khalil, M.H. (1993): Diversity of repeatability between parities for litter traits and reproductive intervals in doe rabbits. World Rabbit Science, 1 (4): 147-154

Khalil, M.H.; Motawei, M.I.; Al-Saef, A.M.; AlSobayil, K.A. and El-Zarei, M.F. (2008): RAPD markers linked to litter, lactation and growth traits in rabbits. 9thWorld Rabbit Congress, genetics, p.143-148.

Kramer, C.Y. (1957) Extension of multiple range tests to group correlated adjusted means. Biometrics, 13, 13-18.

Kuhnlein, U.; Dawe, Y.; Zadworny, D. and Gavord, J.S. (1989) DNA fingerprinting: A tool for determining genetic distances between strains of poultry. Theor. Appl. Genet. 77: 669672

Kunene, N.W.; Bezuidenhout, C.C. and Nsahlai, I.V. (2009): Genetic and phenotypic diversity in Zulu sheep populations: implications for exploitation and conservation. Small Ruminant Research, 84:100-107.

Lynch, M. (1990): The similarity index and DNA fingerprinting. Mol Biol Evol. 7: 478484.

Maciuszonek, A.; Grajewski, B. and Bednarczyk, M. (2005): RAPD-PCR analysis of various goose populations. Folia Biol (Krakow), 53(2):83-8591-696.

Mahfouz, E.R.; Othman, O.E.; Soheir M.E. and El Barody, M.A.A. (2008): Genetic variation between some Egyptian sheep breeds using RAPD-PCR. Research Journal of Cell and Molecular Biology, 2 (2): 46-52.

Mamuris Z.; Sfougaris A.I.; Stamatis C. and Suchentrunk F. (2002) Assessment of genetic structure of Greek brown hare (Lepus europaeus) populations based on variation in random amplified polymorphic DNA (RAPD). Biochem. Genet., 40, 323-338.

Nei M. (1972): Genetic distance between populations. Am Nat 106:283-291.

Nei, M. and Li, W. H. (1979) Mathematical modeling for studying genetic variations in terms of restriction endonucleases. Proc. Natl Acad Sci USA, 76: 5269-5273

Nei, M. (1978). Estimation of average heterozygosity and genetic distances from a small number of individuals. Genetics. 89: 583-590.

Rahimi, G.; Khanahmadi, A.; Nejati-Javaremi, A.and Smailkhanian, S. (2005) : Evaluation of genetic variability in a breeder flock of native chicken based on randomly amplified polymorphic DNA markers. Iranian Journal of Biotechnology, 3 (4): 231-234.

Ramadan, A.M. (2004): Biochemical studies on the identification of meat species by the polymerase chain reaction (PCR). M.Sc. thesis,
Department of Biochemistry, Faculty of Agriculture, Cairo University.

Rangoju, P.K.; Kumar, S.; Kolte, A. P.; Gulyani, R. and Singh, V.K. (2007): Assessment of genetic variability among rabbit breeds by random amplified polymorphic DNA (RAPD) -PCR. World Rabbit Sci., 15: 3 - 8.

Rincón, G.; D'Angelo, M.; Gagliardi, R.; Kelly, L.; Llambí, S. and Postiglioni, A. (2000): Genomic polymorphism in Uruguayan Creole cattle using RAPD and microsatellite markers. Research in Veterinary Science, 69 (2):171-4

Saleh, A. (2011): Genetic Diversity and Phylogenetic Relationships Among Some Breeds of Horses in Egypt. Ph. D. thesis, Faculty of Veterinary Medicine, Zagazig University, Egypt.

SAS (2004). SAS Procedure Guide "Version 6.12 Ed." SAS Institute Inc., Gary,

Sharma, D.; Appa Rao, K.B.C. and Totey, S.M. (2000): Measurement of within and between population genetic variability in quails. British Poultry Science, 41(1): 29-32.

Smith, E.J.; Geng, T.; Long, E.; Pierson, F.W.; Sponenberg, D.P.; Larson, C. and Gogal, R. (2005): Molecular analysis of the relatedness of five domesticated turkey strains. Biochemical Genetics, 43(2): 35-47.

Sodhi, M.; Mukesh, M.; Anand, A.; Bhatia, S. and Mishra, B. P. (2006): Assessment of genetic variability in two north Indian buffalo breeds using random amplified polymorphic DNA (RAPD) markers. AsianAustralasian Journal of Animal Sciences, 19:1234-1239.

Stepniak E.; Zagalska M. and Switonski M. (2002): Use of RAPD technique in evolution studies of four species in the family Canidae. J Appl Genet. 43: 489-499.

Williams J.G.K.; Kubbelik A.R.; Livak K.J.; Rafalski J.A. and Tingey S.V. (1990): DNA polymorphisms amplified by arbitrary primers are useful as genetic markers. Nucleic Acid Res., 18, 6531-6535.

Yeh F.C., Yang R.C., Boyle T. B. J., Ye Z.H., Mao J.X. 1999 POPGENE, the user friendly shareware for population genetic analysis.Molecular Biology and Biotechnology Centre University of Alberta, Canada.

Zhang, X.; Leung, F.C.; Chan, D.K.O.; Yang, G. and Wu, C. (2002): Genetic diversity of Chinese native chicken breeds based on protein polymorphism, randomly amplified polymorphic DNA, and microsatellite polymorphism. Poultry Science, 81:14631472. 